\title{
Gross morphological and angioarchitectural study of the orol cavity in the egyptian domesticated ducks (Anas platy rhynchos domesticus)
}

\author{
Ragab, S.A., Farag, F.M.M., Tolba, A.R., Saleh, A.A. and \\ El-Karmoty, A.F. \\ Anatomy Department, Faculty of Veterinary Medicine, Cairo University
}

\begin{abstract}
The morphology and Angioarchitecture of the Oro-pharynx in the Egyptian domesticated ducks were described. The present work was carried out on ten apparently healthy domestic ducks of different ages and sexes. The ducks were anaesthetized, and then injected through the mandibular artery and cranial vena cava by colored red and blue gum milk latex (60\%), respectively to study the arterial supply and venous drainage. Three specimens were used for the morphological studies; the oral cavity has palatum and lingua. Three birds were prepared to study the arterial supply; the mandibular artery is the main arterial supply of the oral cavity and represents the direct continuation of the external carotid artery. While the remaining four specimens applied to study the venous drainage; the two jagular veins terminated in the oral cavity by forming interjagular anastomosis. The obtained results were photographed, described and discussed with those given by previous authors who performed earlier studies in other species of birds. The nomenclature used was adopted according to the Nomina Anatomica Avium (1993).
\end{abstract}

Key words: Morphology- Angioarchitecture - Egyptian Domestic ducks.

\section{INTRODUCTION}

Ducks belong to family Aythyae which is formed from two breeds; foreign and domestic breeds (anas boscas domesticus). The latter one includes different types; balladi, Muscovy and Pekinese (traditional names).

Ducks are from the lamellirostres because their bills have lamellae that fit with the bristles of the lateral margins of the tongue to sieve the food from the water. (Mally, 2005) and (Mc Lelland, 1990).

In the veterinary occupation and fields, the ducks play an important role as a laboratory birds for some rare and valuable birds (flamingo and Iroquoian geese) due to their similarity in the anatomy of the oral cavity structures. 


\section{Material and methods}

The current study was conducted on ten, apparently healthy domestic ducks of different ages and sexes. Three ducks out of ten were used to describe the oral cavity grossly. The morphometeric study was measured by aid of a Dazor Magnifier and a Vernier Caliber.

The other seven ducks were prepared to study the angioarchitecture of the arterial supply and the venous drainage in the vicinity of the oral cavity.

Before exsanguinations, ducks were anaesthetized by IM injection of 0.5 cc of $2 \%$ xylazine HCL $(3 \mathrm{mg} / \mathrm{kg}$ ) to provide muscle relaxation and to prevent vasoconstriction, followed by the injection of heparin (Cal Heparin, 5000 I.U.) in the wing vein to prevent blood clotting.

Each duck was then exsanguinated through the common carotid arteries and left to bleed for five minutes, the breast muscle and sternum were carefully removed to expose the heart.

To study the arterial supply, Three ducks out of seven were cannulated through the mandibular artery then flushed with normal saline solution and finally were injected by gum milk latex colored red with rottring ink. The remaining four birds were cannulated through the cranial vena cava then flushed with normal saline solution and finally were injected by gum milk latex colored with blue rottring ink to study the venous drainage of the oral cavity.
Injected ducks were left in a mixture of $10 \%$ formalin, $2 \%$ phenol and $1 \%$ glycerin for three days before dissection. The obtained results were photographed using Sony ${ }^{\circledR}$ digital camera 12.1 $\mathrm{mp}, 4 \mathrm{x}$. The nomenclature used was that recommended by the Nomina Anatomica Avium (Baumel et al, 1993).

\section{Results}

Gross morphology of the oral cavity (Cavum oris) :

The roof of the cavum oris is formed from the Palatum:

The palate (fig.1) is about $6.2 \mathrm{~cm}$ in length, deeply concave centrally and fades caudally. From its mucous membrane a ruga palatina mediana (fig. 1/RP) arises as median longitudinal ridge which measures about $3.6 \mathrm{~cm}$. It extended rostrally till about $0.6 \mathrm{~cm}$ beyond the hard keratin tip and terminates caudally forming four based papillae (fig. 1/bp). On both sides of the rostral part of the ridge there are 4-5 short, smooth rugae palatinae laterales and another row of $38-40$ long blades-like pigmented lamellae (fig.1/BL) that lie on the lateral margins of the palate. On the lateral margins of the palate on the ventromedial sides of the bill there is a row of 22- 24 distinct thick lamellae which are about $0.3 \mathrm{~cm}$ rostrally and gradually increase caudally till reach $0.6 \mathrm{~cm}$. The choanal cleft (sulcus palatinus) (fig.1/SP) measures about $2.6 \mathrm{~cm}$ and divides into short narrow rostral 
and long wide caudal parts. The edges of its mucous membrane possess several irregular rows of caudally directed papillae (fig.1/Pp). Caudal to the choanal cleft there is an infundibular slit (fig.1/II) which represents the common narrow opening of the two auditory tubes.

The floor of the cavum oris consists of Lingua, The tongue (Lingua) (figs. 2and 3) is thick, fleshy, elongated, completely fills the floor of the oral cavity and measures about $5.2 \mathrm{~cm}$ length, 1.5 $\mathrm{cm}$ width and $1 \mathrm{~cm}$ in thickness. It consists of three parts; the apex, the body and the root.

The apex of the tongue (Apex linguae) (figs.2 and 3/AL) is narrow, smooth, free from the papillae and reaches to the tip of the lower bill.

The body of the tongue (Corpus linguae) (fig. 3/ CL) is thick and has dorsal, ventral and two lateral surfaces; the dorsum linguae is marked by the sulcus linguae (figs. 2 and $3 / \mathrm{SL}$ ) as a deep median longitudinal groove that is extended from the apex till the torus linguae (figs.2 and 3/TL) and measures about $2 \mathrm{~cm}$ to adapt the median ridge of the hard palate during closure of the oral cavity. From the ventrum linguae arises a sickleshaped fold of mucous membrane representing the frenulum linguae (fig.3/FL) which extends $1-2 \mathrm{~cm}$ from the middle of the ventral surface of the body of the tongue to the floor of the oropharyngeal cavity and this fold measures about $1.2 \mathrm{~cm}$. The margo linguae (fig.3/ML) are fringed with 4-5 large conical papillae (fig.2/CP) and in between them there are numerous fine thread-like papillae that intermingled with the bill lamellae of the palate (figs. 1 and 3/BL).

The root of the tongue (Radix linguae) (fig.3/RL) bears rostrally the triangular wide ridge of mucous membrane, the torus linguae (figs. 2 and 3/TL); its base directed caudally and measures about 1.8 $\mathrm{cm}$. The lateral sides of the torus linguae are marked rostrally by two parallel curved rows of fine papillae and the caudal basal side of the torus is divided by the sulcus linguae into two parts each one contain 4-5 transverse caudally directed papillae (fig. 2/TP). On the floor of the pharynx caudal to the root of the tongue, there is a laryngeal prominence (mound) (figs.2 and 3/LM) as a median mucosal elevation which contains the laryngeal inlet (glottis) (fig. $2 / \mathrm{gl}$ ), it is bounded rostrally by small papillae as well as numerous fine pointed caudomedially directed papillae (fig.2/PH) which are distributed on the terminal part of the laryngeal mound in front of the esophageal inlet (fig.2/OP).

\section{Arteries supplying the oral cavity:}

\section{A.carotis externa:}

The external carotid artery (fig.4/1) is a stout vessel and considered the direct continuation of the common 
carotid artery after emerging of the internal carotid artery. The parent vessel passes rostrally about $0.5 \mathrm{~cm}$ on the medial muscles of the mandible and divides into the maxillary (fig. 4/2) and mandibular (fig. 4/3) arteries.

A.mandibularis:

The mandibular artery (fig. 4/3) is the main arterial supply of the oral cavity and the tongue. It represents the direct continuation of the external carotid artery and passes rostrally about $4 \mathrm{~mm}$ then trifurcated into esophageotracheal trunk, pharyngeal artery and common trunk of the ascending palatine and lingual artery.

\section{Truncus esophageotrachealis:}

The esophageotracheal trunk (fig. 4/4) arises from the medial wall of the mandibular artery and passes obliquely rostodorsally on the mandibular muscles then it divides into the descending esophageal (fig. 4/5) and tracheal (fig. 4/6) arteries.

\section{A.esophagealis descendens:}

The descending esophageal artery (fig. 4/5) erupts from the caudal wall of the parent trunk and directed caudoventrally to ramify on the first part of the cervical esophagus then it anastomoses with the ascending esophageal artery by fine twigs.

\section{A.pharyngealis:}

The pharyngeal artery (fig. 4/8) is considered as the middle branch of the mandibular artery and passes parallel to the other branches till it reaches the lateral wall of the oropharynx then it ramified into 2-3 fine branches that supply the pharynx.

\section{A.palatini ascendens:}

The ascending palatine artery (fig. 4/7) erupts with the lingual artery by a common trunk from the parent artery and is directed rostodorsally towards the medial wall of the chonal cleft to supply it by 2-3 fine branches then terminated by 2-3 fine twigs that supply the palate.

\section{A.lingualis:}

The lingual artery (fig. 4/9) arises from the ventromedial wall of the common trunk and is arborized into 3-5 fine twigs that supply the tongue and its muscles.

\section{Veins draining the oral cavity:}

\section{Vv.jugulares:}

The jugular veins (fig. 5/8) are two stout vessels, that proceed rostodorsally for about $5 \quad-7 \quad \mathrm{~cm}$ from the crop and passes on the corresponding side of the esophagus. During its course, it related to the common carotid artery and the trachea till reaching about $1-1.5 \mathrm{~cm}$ behind the auditory tube opening; the two jugular veins are terminated by forming interjugular anastomoses (fig.5/10). Along its course, it receives the esophageotracheobronchial, ascending esophageal, esophageal, maxillary, esophageotracheal trunk, descending pharyngeal and rostral cephalic veins.

\section{V. esophagealis descendens:}

The descending esophageal vein (fig.5/6a) drains into the esophageotracheal trunk and extends caudoventrally where it 
received by 3 - 4 fine veinules on the initial part of the cervical esophagus.

\section{V.pharyngealis descendens:}

The descending pharyngeal vein (fig.5/5) emanates about $0.5 \mathrm{~cm}$ rostral to the esophageotracheal trunk from the jugular vein and passes obliquley rostoventrally on the hyopharyngeal muscles where it terminated at the junction between the cranial border of the oropharynx and the ventral border of the laryngeal mound then drained by 2 3 fine twigs.

V.Truncus communis palatina lateralis et lingualis propria:

The common trunk of the lateral palatine and proper lingual veins (fig.5/4) was about $0.5 \mathrm{~cm}$ in length, extends from the right dorsal wall of the rostral cephalic vein (fig.5/7) and proceeds rostodorsally on the pterygopalatine muscles then bifurcates into lateral palatine (fig.5/1) and proper lingual (fig.5/3) veins.

\section{V.palatina lateralis:}

The lateral palatine vein (fig.5/1) is the direct continuation of the parent trunk in ducks and extends obliquely craniodorsally on the lateral border of the chonal cleft till reaching the angle of the mouth where it terminates into medial palatine and sublingual veins.
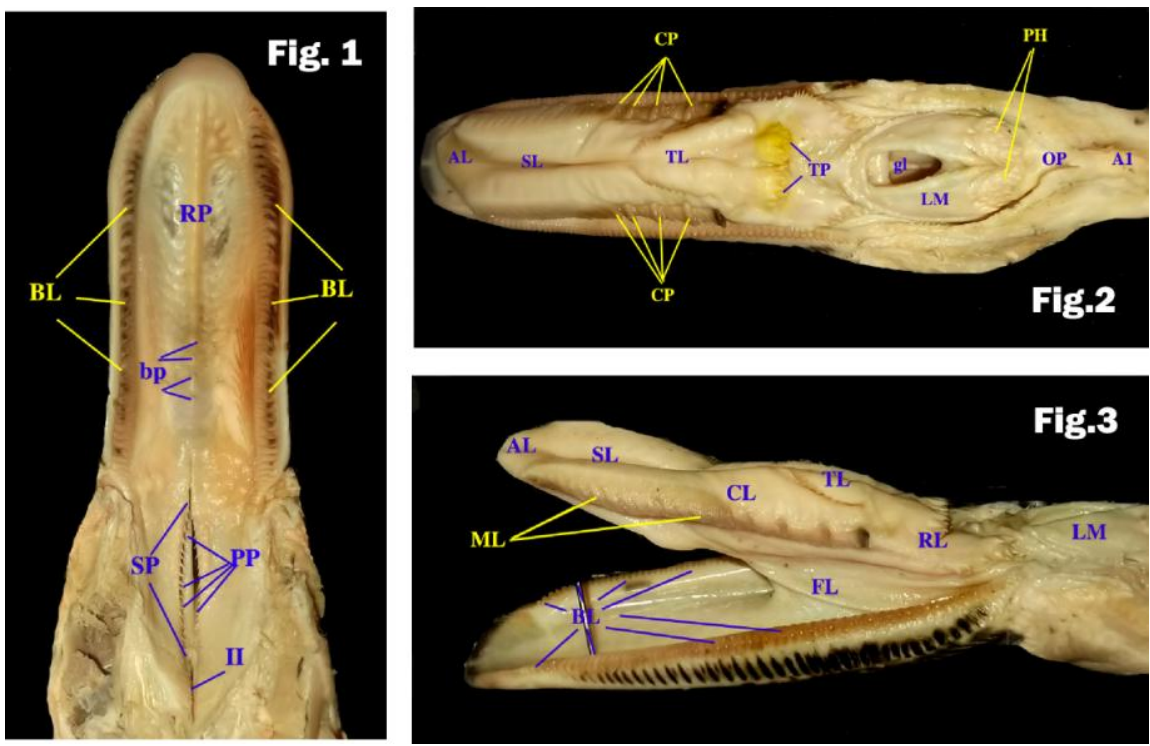

Fig. (1): A photograph showing the roof of oral cavity of the duck. Fig. (2): A photograph showing the floor of oral cavity of the duck. Fig. (3): A photograph showing the tongue and the floor of the oral cavity in the duck. (Lateral view) 


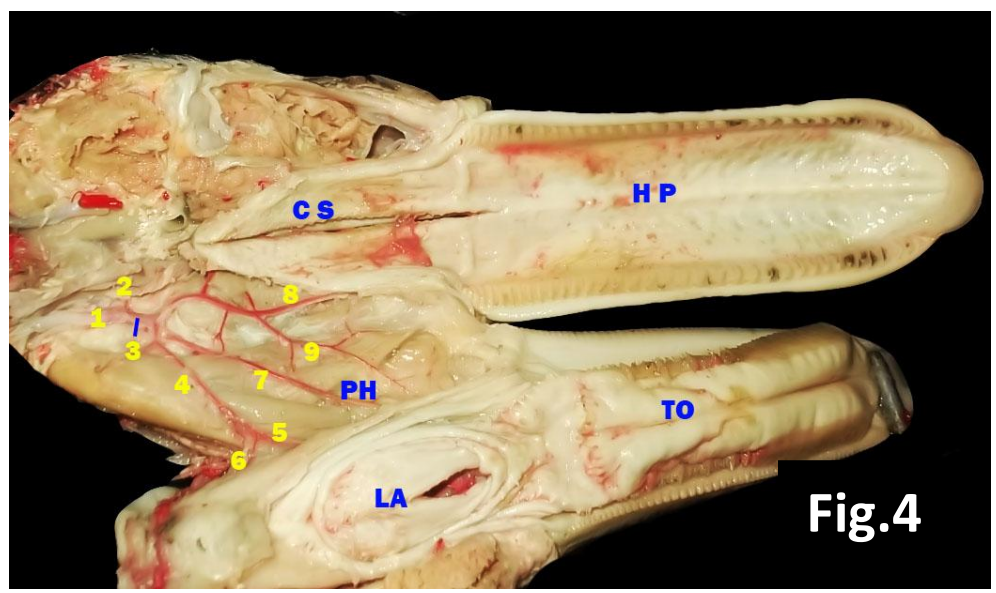

Fig. (4): A photograph showing the branches of the common carotid artery in oral cavity of the duck. (Right dorsal view).

1. A. carotis Externa. 2. A. Maxillaris. 3. A. Mandibularis 4. Truncus esophageotrachealis. 5. A. esophagealis descendens 6. A. trachealis descendens. 7. A. palatina ascendens. 8. A. pharyngealis. 9. A. lingualis HP. Hard Palate TO. Tongue CS. Chonal slit PH. Pharynx LA. Larynx .

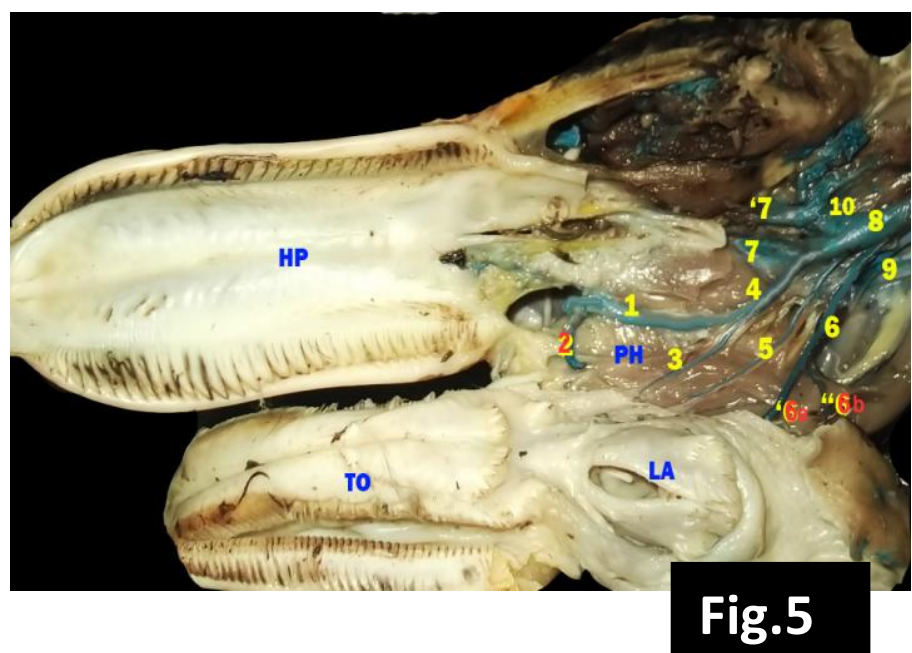

Fig. (5): A photograph showing the jagular vein trmoutarres in the oral cavity in duck. (Left dorsal view)

1 V. palatina lateralis. 2. V. sublingualis 3. V. lingualis propria 4. V. Truncus communis vein et $1 \& 3 \quad 5$. V. pharyngealis descendens $6 . \mathrm{V}$. truncus esophageotrachealis $6 \mathrm{a}$. V. esophogealis descendens $6 \mathrm{~b}$. V. trachealis descendens 7. Vv.cephalica rostralis $8 . \mathrm{V}$. jugularis 9. V. maxillaris 10. Inter jugular anastomosis HP. Hard Palate TO. Tongue PH. Pharynx LA. Larynx. 


\section{Legend of figures (1-5)}

AL: Apex linguae.- CL: Corpus linguae - RL: Radix linguae - SL: Sulcus linguae - TL: Torus linguae - FL: Frenulum linguae - ML: Margo linguae - CP: Conical papillae. - TP: Transverse papillae. - gl: Glottis. LM: Laryngeal mound. - PH: Pharyngeal papillae - BL: Bill lamellae.- OP: Oropharynx. - RP: Ruga palatina mediana - bp: Based papillae. - SP: Sulcus palatinus. - II: Infundibular slit.- PP: Papillae. - AL: Apex linguae. - CL: Corpus linguae. - RL: Radix linguae. - SL: Sulcus linguae. - TL: Torus linguae - FL: Frenulum linguae. - ML: Margo linguae. - CP: Conical papillae. - TP: Transverse papillae. - gl: Glottis. - LM: Laryngeal mound. PH: Pharyngeal papillae.- BL: Bill lamellae. - OP: Oropharynx.- RP: Ruga palatina mediana. - bp: Based papillae.- SP: Sulcus palatinus. - II: Infundibular slit. - PP: Papillae.

\section{Discussion}

\section{Regarding the gross morphology} of the oral cavity:

Our findings have a similar opinion to that seduced by some available literatures where the soft palate was absent, consequently, there was a common oropharyngeal cavity, its roof formed by the hard palate which oriented by the choanal cleft followed by the infundibular slit and the vicinity of its floor occupied by the tongue.

In agreement with our study, Hanna et al (2011) in domestic goose, Igweubike and Eze (2010) in African pied crow, Dursun (2002) in domestic fowls, Nickel et al (1977) in fowls and pigeons and Mc Lelland (1968) in chicken have the opinion that the tongue was divided into three parts; apex, body and root.

Concerning the torus linguae of the examined ducks, it was a triangular wide ridge of mucous membrane where its base directed caudally and its lateral sides were marked rostrally by two parallel curved rows of fine papillae and the caudal basal side of the torus linguae was divided by the sulcus linguae into two parts; each one contained 4-5 caudally directed papillae. On the other hand, Hanna et al (2011) in domestic goose said that the body of the tongue ended by a lingual prominence, Mally (2005) and Mc Lelland (1990) in ducks, geese and swans asserted that the tongue had the fleshy caudal eminence that was called the torus linguae and $\boldsymbol{M c}$ Lelland (1968) in duck and goose observed that the terminal part of the tongue contained a wide ridge of the mucous membrane in duck while in goose it was replaced by the caudal raised part.

The tongue of ducks in our study was thick, fleshy, elongated and completely fills the floor of the oral cavity with narrow, smooth apex free from any mechanical papillae. On the other hand, Hanna et al (2011) in goose defined that the tongue was narrow elongated, 
Igweubike and Eze (2010) in African pied crow said that it was arrow shaped, Dyce, sack and wensing (2010) in birds revealed that the tongue was triangular in its outline, Catarina (2008) in ostrich observed that it was a small, stubby and $\mathrm{u}$-shaped structure with a blunt apex, Mally (2005) and Mc Lelland (1990) in ducks, geese and swans mentioned that the tongue was thick and fleshy with the rostral border modified into a scoop while in flamingo it was piston-like. The latter authors in psittacine species stated that the tongue was short, blunt and fleshy and Nickel et al (1977) in pigeon cited that the tongue was narrow and in fowl it was broad, lancet-shaped. Moreover, Mc Lelland (1968) in duck asserted that the long free part of the tongue was narrow at the rostral extremity and in goose it was spatula shaped with rounded rostral extremity and the latter author in chicken added that the tongue was relatively rigid triangular.

The frenulum lingua of the examined birds was insinuated between the ventral surface of the body of tongue and the floor of the oral cavity. This statement was similar to that described by Hanna etal (2011) in goose, Igweubike and Eze (2010) in African pied crow , Catarina (2008) in ostrich, Nickel etal (1977) in birds and Mc Lelland (1968) in chicken.

In the present ducks, the dorsum linguae of the tongue was marked by a deep median sulcus linguae which extended from its apex to the base. This result was agreed with that given by Hanna et al (2011) in goose, Hassan et al (2010) in the Egyptian geese and Mally (2005) and Mc Lelland (1990) in ducks, geese and swans. However, Catarina (2008) in ostrich observed that the dorsal surface of the tongue was folded back on itself to form a deep blind pocket.

In the investigated ducks, it was revealed that the margo linguae are fringed with 4-5 large conical papillae and in between them there are numerous fine thread like papillae that intermingled with the bill lamellae of the palate. These results were nearly similar to that asserted by Hanna et al (2011) and Hassan et al (2010) in geese, Dyce etal., (2010) in ducks and geese, Mally (2005) and Mc Lelland (1990) in ducks, geese and swans and Mc Lelland (1968) in duck.

The current study confirmed that the mucous membrane of the palate was oriented by a ruga palatina mediana as median longitudinal ridge which measures about $3.6 \mathrm{~cm}$. It extended rostrally till beyond the hard keratin tip by about $0.6 \mathrm{~cm}$ and terminates caudally to form four based papillae. However, Catarina (2008) in ostrich, who reported that the roof of the oropharynx divided into two halves by a prominent median palatine ridge. Furthermore, Nickel et al (1977) in fowl and pigeon and Mc Lelland (1968) in chicken described that the hard palate had a median and two lateral 
palatine ridges. Moreover, the latter author in duck and goose observed that the rosral part of the hard palate had a longitudinal median ridge.

In the studied ducks, the rostral part of the ridge was formed by 4-5 short, smooth rugae palatinae laterales. On the lateral margins of the palate close to the ventromedial edge of the upper bill there is a row of 38-40 long blade like pigmented lamellae. On the lateral margins of the palate on the ventromedial sides of the bill there is a row of 22- 24 distinct thick lamellae which are about $0.3 \mathrm{~cm}$ rostrally and gradually increase caudally till reach $0.6 \mathrm{~cm}$. These statements nearly similar to that concluded by Nickel et al (1977) in lamellirostres and $\mathbf{M c}$ Lelland (1968) in duck and goose.

The results under discussion achieved that the choanal cleft in the examined birds divided into short narrow rostral and long wide caudal parts. The edges of the mucous membrane of the cleft were covered with several irregular rows of caudally directed papillae and caudal to the preceeding cleft there was the infundibular slit as a narrow common opening of the two auditory tubes. These statements might be attributed to that noted by Mc Lelland (1968) in duck and goose. In contrary with Igweubike and Eze (2010) in the African pied crow who assessed that in the midline of the hard plate there was choana which was characterized by a longitudinal fissure and divided into a narrow rostral and an enlarged caudal portions. The authors added that the mucous membrane of the hard palate exhibited many caudally directed papillae that were prominent on the palatine ridges and on the edges of the enlarged portion of the choanal slit. However, Dyce et al (2010) in birds said that the palate presented a long median choanal cleft which was connected with the nasal cavity. Moreover, Catarina (2008) in ostrich reported that the roof of the oropharynx had inverted Vshaped depressed choana which bounded caudally by a shallow crescent that demarcated the median infundibular cleft. Furthermore, $\boldsymbol{M c}$ Lelland (1968) in chicken stated that the roof of the oral cavity contained papillae that directed caudally and arranged in transverse rows. Two rows arranged immediately rostral to the choanal slit and two rows on each sides of this slit. The roof of the pharynx was divided by a short median longitudinal infundibular slit.

\section{Regarding the arterial supply and venous drainage of the oral cavity:}

The current study revealed that the esophageotracheal trunk of the ducks arises from the medial wall of the mandibular artery and divides into the descending esophageal and tracheal arteries, simulating what was observed as represented by Baumel (1975). On the other hand Nickel et al (1977) revealed that this trunk arose from the sublingual artery. 
In viewing of the present findings, the lingual artery arises by a common trunk with the ascending palatine artery from the mandibular artery in ducks and divided rostrally into the proper lingual and sublingual arteries. In this respect, Baumel (1968) in fowl cited that the lingual artery as a rostromedial branch of the mandibular artery while Holliday et al (2006) in flamingo referred to the indicated vessel as a detached branch from the hyolingual artery of the common carotid artery.

The descending pharyngeal vein in the examined ducks emanated directly from the jugular vein, and passed obliquley rostroventrally on the hyopharyngeal muscles where it terminated by $2-3$ fine twigs at the junction between the rostral border of the oropharynx and the ventral border of the laryngeal mound. On the other hand, the corresponding vein was named the dorsal pharyngeal vein which drained indirectly into the jugualr vein via the internal facial of the internal cephalic vein ( Nickel et al, 1977) or it drained into the rostral cephalic before the interjagular anastomosis as cited by Baumel (1968) in birds. In the examined ducks, the lingual vein arose by a common trunk with lateral palatine vein. The trunk extended from the right dorsal wall of the rostral cephalic vein and proceeds rostrodorsally on the pterygopalatine muscles then bifurcates into lateral palatine and sublingual veins. In contrast to the opinion of Nickel et al (1977) which observed that the indicated vein received blood from the tongue and joined the external cephalic vein of the jugular trunk. Moreover, Baumel (1968) mentioned that the lingual vein was a rostral tributary of the mandibular of the rostral cephalic vein and received blood from the proper lingual and the sublingual veins.

Concerning the origin of the esophageotracheal trunk in the studied ducks which arose from the right ventrolateral wall of the jugular vein, contrary to what mentioned by Baumel (1968) who have the opinion that the corresponding trunk was the caudal tributary of the mandibular vein of the rostral cephalic. However, Nickel et al (1977) demonstrated that the esophageal and the tracheal veins arose separately from the jugualr vein. In our investigations, it was found that the esophageotracheal trunk ramified into the descending esophageal and tracheal veins, similar to the statement of Baumel (1968) in birds.

\section{References}

Baumel, J. J. (1968): Coração e vasossangüíneos das aves. In: GETTY, R. Sisson/ Grossman anatomia dos animais domésticos. 5. ed. Rio de Janeiro: Guanabara Koogan, v. 2, p. 1842-1880.

Baumel, J.J. (1975) : Aves Heart and Blood Vessels. In Sisson and Grossman's the Anatomy of the 
Domestic Animals. Getty R (Eds.), Vol. II, $5^{\text {th }}$ ed. Saunders Company, Philadelphia, 1990-1991.

Baumel, J.J., King, S.A., Breasile, J.E., Evans, H.E. and Berge, J.C.V. (1993) : Nomina Anatomica Avium. Published by the Nuttall Ornithological Club. No: 23, Cambridge, Massachusets.

Catarina, T. (2008) : The morphology of the oral cavity, pharynx and esophagus of the ostrich (struthio camelus). (Mvsc degree) anatomy and physiology department faculty of vet. Science of pretoria university.

Dursun, N. (2002) : Anatomy of Domestic Birds. Medisan Publishing,Ankara. 140-141.

Dyce, K.M., Sack, W.O. and wensing, C.J.G (2010) : Text book of veterinary anatomy ( $4^{\text {th }}$ edition). El Sevier Saunders, 350-355.

Hanna, J., Kinga, Godynicki, S.S., Iwasaki, S.I. and Meyer (2011). Functional Morphology of the tongue in the Domestic Goose (Anser Anser f. Domestica). The anatomical record 294:1574-1584.

Hassan, M.S., Moussa, E.M. and Cartwright, E.L. (2010) : Variations by Sex in Anatomical and Morphological Features of the Tongue of Egyptian Goose (Alopochen aegyptiacus). Cells Tissues Organs (DOI:
10.1159/000223231) Published Research Articles in International Journals 2009-2010.

Holliday, C.M., Ridgely, R. C., Balanoff, A. M. and Witmer, L. M. (2006) : Cephalic vascular anatomy in flamingos (phoenicopterus ruber) based on novel vascular injection and computed tomographic imaging analyses, the anatomical record part A 288A:1031-1041.

Igweubike, u.M. and Eze, U.U.( 2010) : Anatomy of oropharynx and tongue of the African pied crow(corvus albus). Vet. arhiv 80, 523-531.

Mally, B.O. (2005). Clinical anatomy and physiology of exotic species (structure and function of mammals, birds, reptiles and amphibians. El Sevier Saunders; Edinburg London newyork Oxford Phiadelphia $\mathrm{Tt}$ Louis Sydney Toronto 2005.

Mc Lelland, J. (1968) : Anatomy of the avian cecum. Journ. Exp. Zool. Suppl. 1989; 3:2-9.

Mc Lelland, J. (1990) : A colour atlas of avian anatomy. W.B.philadelphia, London, Toronto, montreal, Sydney, Tokyo.

Nickel, R., Schummer, A. and Seiferle, E. (1977) : Anatomy of the Domestic Birds. Berlin:Verlag Paul Parey. 96-99 and 101-103. 


\section{الملخص \\ دراسة المورفولوجي و التصميم الوعائي للتجويف الفمي في البط المصري المستأنس الوعن}

أجري البحث على عثر من البط المصري صحيحة ناضجة من كلا الجنسين لأجل الدر اسة العيانيه.

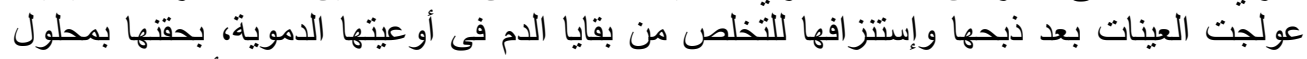

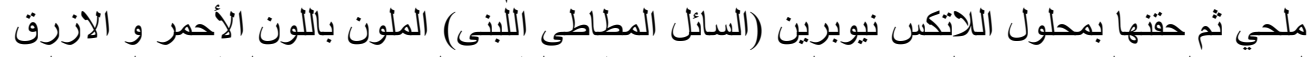

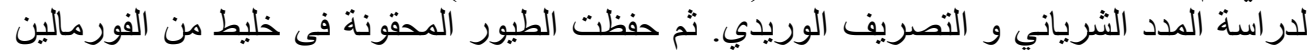

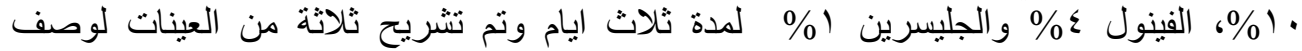

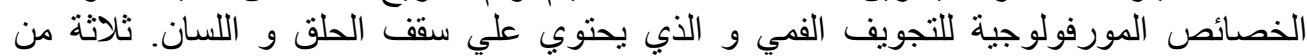

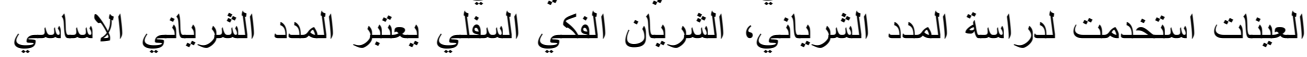

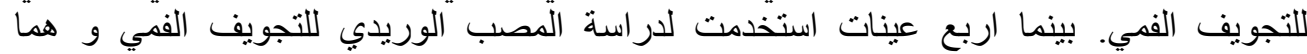
الوريدان الوداجيان. تم إعتماد المسميات واستخدام المصطلحات التشريحية البيطرية الدولية للطيور

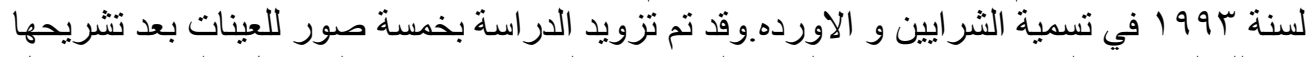

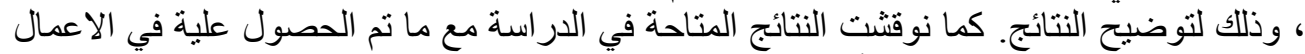
السابقة في الدواجن و الطيور المستأنسة. 